\title{
CORRIGENDUM
}

\section{PGC-1a mediates mitochondrial biogenesis and oxidative phosphorylation in cancer cells to promote metastasis}

Valerie S. LeBleu, Joyce T. O’Connell, Karina N. Gonzalez Herrera, Harriet Wikman, Klaus Pantel, Marcia C. Haigis, Fernanda Machado de Carvalho, Aline Damascena, Ludmilla Thome Domingos Chinen, Rafael M. Rocha, John M. Asara and Raghu Kalluri

Nat. Cell Biol. 16, 992-1003 (2014); published online 21 September 2014; corrected after print 25 September 2014

In the version of this Article originally published, the number of patients who were PGC-1 $\alpha$ with detected CTCs in Fig. $8 \mathrm{f}$ should have read ' $n=2$ (18.2\%)'. This error has now been corrected in the online version of the Article. 